\title{
EFFECTS OF SWITCHING SOYBEAN MEAL WITH GUAR MEAL IN BROILER DIETS ON PERFORMANCE, CARCASS CHARACTERISTICS AND SOME BONE MEASUREMENTS
}

\author{
A.I. El-Faham ${ }^{1}$; A. Abd El-Maksoud ${ }^{2}$; A.M.H. Ahmed ${ }^{1}$ and E.M. Khalifa ${ }^{2}$ \\ ${ }^{1}$ Poultry Production Dept., Fac. of Agric., Ain Shams Univ., Egypt. \\ ${ }^{2}$ Anim. and Poult. Nutrition Dept., Desert Res. Center, El-Mataria, Cairo, Egypt.
}

\section{SUMMARY}

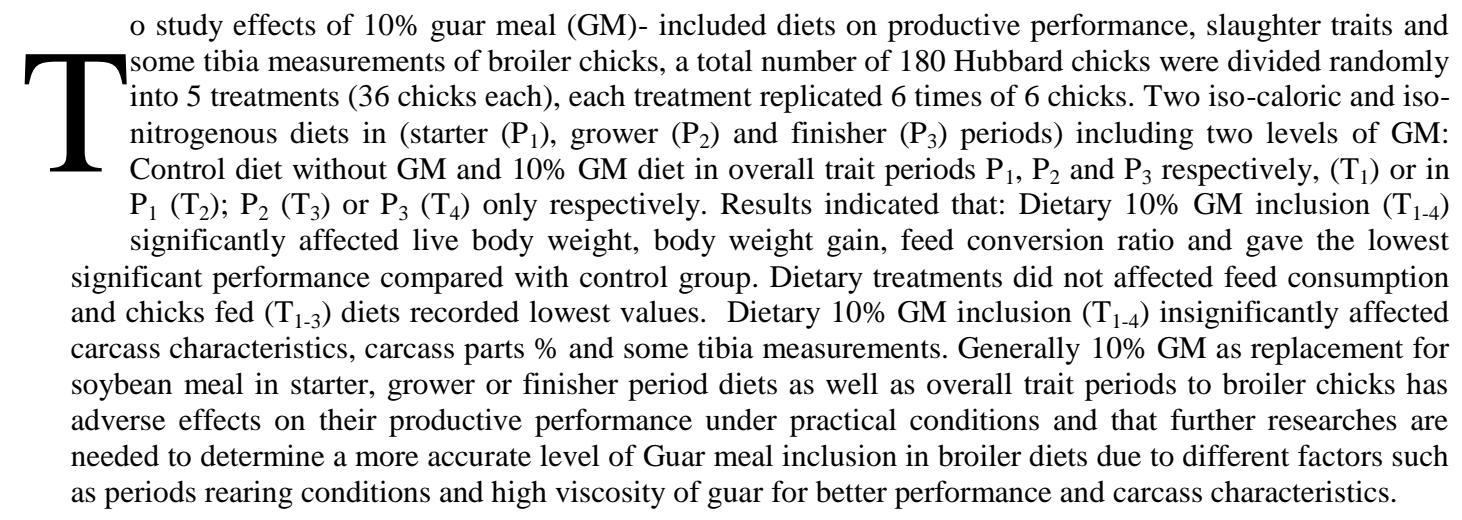

Keywords: guar meal, performance, carcass characteristics and broiler chicks

\section{INTRODUCTION}

Guar, Cyamposis tetragonoloba, is primary used in the gum industry because its seeds contain high amount of guar gum. To produce gum, guar seeds are split, yielding both a high protein germ fraction and a lower protein husk fraction as byproducts.

These two fractions are usually recombined to create guar meal with a crude protein level of 35 to 47.5\% depending on the relative concentration of the two fractions (Ambegaokar et al., 1969).

Guar meal (GM) typically comes in granular form and their average composition is $50 \%$ (min) crude protein, $7 \%(\max )$ crude fat, $8 \%(\max )$ moisture, $5 \%(\max )$ fiber and $1 \%(\max )$ sand/silica, Srivastava et al., (2011).

Kamran et al. (2002) reported that, since the germ fraction of GM contains energy, protein, methionine and phosphorus in higher levels than in soybean meal, addition of GM as a partial replacement $(<10 \%)$ of soybean in poultry diets may be a useful economic strategy for decreasing feed costs without any negative effects on production.

On the other hand, some of anti-nutritional agents (gum residue, saponins and trypsin inhibitor) present in GM limit its usage at high level in broiler diets (Anderson and Warnick, 1964, Cheng, 2004 and Lee et al., 2004).

An experiment was carried out by Lee et al. (2005) to study the effect of feeding broiler chickens diets containing guar germ, guar hull or guar meal at 4 levels $(2.5,5.0,7.5$ and 10.0\%) compared with a negative control diet. Results indicated that any of 3 guar fraction could be fed at a $2.5 \%$ dietary inclusion rate without adversely affecting broiler chickens growth, whereas broilers fed diets containing $10 \%$ had the lowest cumulative body weight at 6 weeks of age.

More recent studies (Tammam, et al., 2015) were designed to assess the effect of partial and total substitution of soybean meal with guar meal in balance starter/ grower/ finisher diets containing $0,12.5$, 


\section{El-Faham et al.}

25,50 and $100 \%$ Guar meal. The results indicate that replacing soybean meal with guar meal at the tested levels in broiler chicks diets had a significant effect on body weight gain, feed intake, feed conversion ratio, slaughter parameters, carcass parts $(\%)$ and gave the lowest economic and relative efficiency values when compared with control ( $0 \%$ gaur meal).

To minimize the negative effects of guar meal in broiler diets, the amount included in the diets restricted to $2.5 \%$ Lee et al. (2005) or $6.0 \%$ Mohammad et al. (2012). Moreover, supplementing the guar meal diets with enzymes (Lee et al., 2003b, Daskiran et al., 2004; Mevliit et al., 2004 and Elham, 2016), prebiotics (Gibson and Roberfroid, 1995 and Hajati and Rezaei, 2010), probiotics (Sanders and Veld, 1999) or prebiotic and probiotic (Hajali et al., 2012) or combinations of autoclaving and enzyme supplementation (Patel and McGinnis, 1985) or combinations of roasted treatment and enzyme supplementation (Michele et al., 2000) has failed to overcome growth-inhibitor properties of guar meal.

Therefore, the objective of this experiment was to study the impact of switching from soybean meal to guar meal based diet in starter phase, grower phase or finisher phase on broiler performance, carcass characteristics and some bone measurements.

\section{MATERIALS AND METHODS}

The current study was conducted at poultry experimental and research station at Shalakan, Faculty of Agriculture, Ain Shams University, in order to evaluate and compare the differences in productive performance, slaughter traits and some tibia measurements of broiler chicks switching from soybean meal to $10 \%$ guar meal based diets in (starter, grower or finisher phase).

A total number of 180 Hubbard broiler chicks, one day old were distributed into five dietary treatments. Every treatment had six replicates of six chick each. The treatments are summarized in Table (1). Two experimental diets were formulated in which (control diets) were $0.0 \%$ guar meal, in the other diets guar meal were incorporated at level of $10 \%$ to obtain, starter, grower and finisher experimental diets. Diets were formulated to meet the nutrient requirements of the broiler chicks according to guidebook of Hubbard broiler to be isocoloric and isonitrogenous according to Hubbard manual for broiler chicks and were offered in mash form.

\section{Table (1): Experimental design}

\begin{tabular}{lccccc}
\hline \multirow{2}{*}{ Experimental periods* } & & \multicolumn{3}{c}{ Treatments* } \\
\cline { 2 - 6 } & Control & T1 & T2 & T3 & T4 \\
\hline Starter (P1) & SM $^{* *}$ & GM** & GM & SM & SM \\
Grower (P2) & SM & GM & SM & SM & GM \\
Finisher (P3) & SM & GM & SM & SM
\end{tabular}

*P1 (1-10 day), P2 (11-22 day), P3 (23-35 day).

** SM=Soybean meal based diet (0 \% Guar meal), GM= Guar meal based diet (10\%Guar meal)

During the first 10-day starting period $\left(\mathrm{P}_{1}\right)$ chicks in $\mathrm{T}_{3}$ and $\mathrm{T}_{4}$ were fed a common experimental diet with soybean meal $(\mathrm{SM})$ as the protein source. During the second 12-day $\left(\mathrm{P}_{2}\right)$ or third 13-day $\left(\mathrm{P}_{3}\right)$, all chicks in treatments $T_{3}$ and $T_{4}$ were switched to guar meal (GM) based diets respectively. Chicks in treatment $T_{2}$ were fed guar meal based diet during $\mathrm{P}_{1}$, while during $\mathrm{P}_{2}$ and $\mathrm{P}_{3}$ chicks were switched to (SM) based diets. In the same order during, $\mathrm{P}_{1}, \mathrm{P}_{2}$ and $\mathrm{P}_{3}$ periods all chicks in control or $\mathrm{T}_{1}$ were fed (SM) or (GM) diets, respectively. The chemical composition of guar meal has been estimated to be crude protein, $49.6 \%$ either extract, $7.07 \%$, crude fiber, $7.66 \%$ and ash, 6.13\%. All chicks were reared under similar management and hygienic conditions. Feed and water were provided ad libitum. Body weights and feed consumption were weekly recorded and body weight gain, feed conversion were calculated. Mortality rate was daily recorded.

At the end of experiment ( 35 days of age) four chicks of each dietary treatment were randomly taken and slaughtered to complete bleeding, followed by plucking the feathers. After removal of head, viscera, 
shanks, spleen, gizzard, liver, heart and abdominal fat, the rest of the body was weighed to determine dressed weight. Weights of different parts of carcass (wing, breast, thigh and drumstick) were recorded to the nearest gm.

Right tibia were removed and cleaned from soft tissues, then weighed and length, width of each was measurements using caliper to the nearest $\mathrm{mm}$. The tibia were dried $\left(105^{\circ} \mathrm{c}\right.$ for $3 \mathrm{hrs}$.) weighed and tibia Seedor Index were calculated according to Seedor et al. (1991).

Data were processed by one way ANOVA analysis of variance using general linear model (GLM) procedure of SAS software (SAS, 2004) User's guide and individual effects of experimental groups were compared using Duncan (1955) multiple range tests at a level equal to 0.05 or 0.01 .

\section{RESULTS AND DISCUSSION}

\section{Productive performance}

Growth performance of broiler chicks fed experimental diets (starter, $\left(\mathrm{P}_{1}\right)$, grower, $\left(\mathrm{P}_{2}\right)$ and finisher $\left(\mathrm{P}_{3}\right)$ of control $(0 \% \mathrm{GM})$ and $10 \% \mathrm{GM}$ are shown in Tale 3 . It is clear that initial live body weight at 1 day of age diet not differ among the experimental groups and the corresponding values ranged between 41.14 and $42.55 \mathrm{~g}$. The live body weight and weight gain of broiler chicks fed (GM) experimental diets $\left(\mathrm{T}_{1-4}\right)$ during whole experimental period (0-35 days of age) reflect the lowest significant results in both body weight and weight gain compared with control group.

On the other hand, chicks fed 10\% GM during whole experimental period $\left(\mathrm{T}_{1}\right)$ gave slightly lower live body weight (1427.21 g) compared to those fed $10 \%$ GM during $\mathrm{P}_{1}, \mathrm{P}_{2}$ and $\mathrm{P}_{3}\left(\mathrm{~T}_{2-4}\right)$, being 1571.83, 1532.28 and $1519.64(\mathrm{~g})$ respectively, the differences were statistically not significant.

The same trend was observed by some investigators (Lee et al., 2003a; Lee et al., 2003b; Lee et al., 2005 and Mohammed et al., 2012) who stated that the lower dietary levels of GM supported chick growth compared with those fed higher levels and Lee et al. (2005) showed that the 3 GM (guar germ, guar hull or guar meal) can be safely fed at $2.5 \%$ dietary inclusion rate without adversely affecting broiler chickens growth to 6 wks of age, whereas broilers fed diets containing $10 \%$ of any guar fraction had the lowest cumulative body weight at 6 weeks of age. On the other hand, these findings were in contrast with the results obtained by Tyagi et al. (2011) who concluded that roasted GM could replace soybean meal up to $10 \%$ in starter and grower periods without any adverse effect on performance of broiler chicks.

\section{Feed consumption and feed conversion}

The results of feed intake showed that chicks fed the experimental diet containing $10 \% \mathrm{GM}\left(\mathrm{T}_{1-3}\right)$ had the lowest feed consumption being 3.90, 3.46 and 5.81\% lower than that of chicks on control diet, respectively during the period from 0 to 35 days of age, differences were statistically not significant. However, chicks fed control diets or diets containing $10 \% \mathrm{GM}\left(\mathrm{T}_{4}\right)$ consumed more feed than the other dietary treatments and corresponding values ranged between 2739.33 and $2756.00 \mathrm{~g}$ and the differences insignificant. The results of feed conversion ( $\mathrm{g}$ feed/ g gain) showed significant differences during whole experimental period and chicks fed control diets recorded the best feed conversion (1.56) followed by those fed $10 \%$ Guar meal during starting $\left(\mathrm{T}_{2}\right)$ or growing $\left(\mathrm{T}_{3}\right)$ periods being (1.74 or 1.73), respectively, while those fed $10 \%$ GM during whole experimental period $\left(\mathrm{T}_{1}\right)$ as well as during finishing period $\left(\mathrm{T}_{4}\right)$ showed the worst values being (1.90 and 1.87) respectively.

The current results of broiler productive performance (Table 2) showed that chicks fed control diets $(0.0 \% \mathrm{GM})$ during the whole experimental period (0-35 days of age) reflected the highest values in body weight gain and the best value of feed conversion compared by those fed 10\% GM during starting $\left(\mathrm{T}_{2}\right)$, growing $\left(\mathrm{T}_{3}\right)$, finishing $\left(\mathrm{T}_{4}\right)$ as well as during whole experimental period $\left(\mathrm{T}_{1}\right)$.

These results are in agreement with the results of Saxena and Pradhan (1974), Vohra and Kratzer (1964a), Conner (2002) and Lee et al. (2003a). In the same order, Larhang and Torki (2011) concluded that, dietary inclusion for 4 or $8 \%$ GM had no significant effect on feed intake, while diet inclusion of $8 \%$ GM significant increased (depressed) FCR of broilers compared to that of birds fed the control diet. These findings were in contrast with the results obtained by Mohammed et al. (2012) who concluded that broiler 
chick were able to utilize up to $9 \%$ of GM without any significant adverse effect on feed consumption and feed conversation ratio. This may be due to the fact that unpalatability of the diet and to the residual gum content of the meal (Vohra and Kratzer, 1964b and Lee et al., 2005). The residual gum due to its sticky nature, will increase the passage of ingesta in the intestines, resulting in a lower feed utilization, a lower body weight and resulting in poor feed conversion (Lee et al., 2003b).

Table (2): Effect of feeding different dietary treatments on productive performance of broiler chicks (0-35) days of age.

\begin{tabular}{|c|c|c|c|c|c|c|}
\hline \multirow{2}{*}{ Item } & \multicolumn{6}{|c|}{ Treatments } \\
\hline & Control & $\mathrm{T} 1$ & $\mathrm{~T} 2$ & T3 & $\mathrm{T} 4$ & Sig \\
\hline \multicolumn{7}{|c|}{ Initial body weight (g) } \\
\hline & 42.55 & 41.14 & 41.93 & 42.22 & 41.60 & N.S \\
\hline \multicolumn{7}{|c|}{ Final live body weight (LBW) (g) } \\
\hline & $1804.00 \pm 38.91^{\mathrm{a}}$ & $1427.21 \pm 55.18^{\mathrm{b}}$ & $1571.83 \pm 71.85^{\mathrm{b}}$ & $1532.28 \pm 54.68^{\mathrm{b}}$ & $1519.64 \pm 41.61^{\mathrm{b}}$ & $* *$ \\
\hline$\%$ & 100 & 79.11 & 87.13 & 84.93 & 84.23 & \\
\hline \multicolumn{7}{|c|}{ Body weight gain (BWG) (g) } \\
\hline & $1761.45 \pm 38.89^{\mathrm{a}}$ & $1386.08 \pm 55.16^{\mathrm{b}}$ & $1529.90 \pm 71.85^{b}$ & $1490.06 \pm 54.74^{\mathrm{b}}$ & $1478.04 \pm 41.60^{\mathrm{b}}$ & $* *$ \\
\hline & 100 & 78.69 & 86.85 & 84.59 & 83.91 & \\
\hline \multicolumn{7}{|c|}{ Feed consumption $(\mathrm{g})$} \\
\hline & $2739.33 \pm 34.90$ & $2632.51 \pm 74.30$ & $2644.66 \pm 55.81$ & $2580.00 \pm 75.02$ & $2756.00 \pm 18.08$ & N.S \\
\hline$\%$ & 100 & 96.10 & 96.54 & 94.19 & 100.6 & \\
\hline \multicolumn{7}{|c|}{ Feed conversion ratio } \\
\hline & $1.56 \pm 0.019^{c}$ & $1.90 \pm 0.037^{\mathrm{a}}$ & $1.74 \pm 0.052^{\mathrm{b}}$ & $1.73 \pm 0.018^{b}$ & $1.87 \pm 0.045^{\mathrm{a}}$ & $* *$ \\
\hline$\%$ & 100 & 121.79 & 111.53 & 110.89 & 119.87 & \\
\hline Mortality rate & $3 / 36$ & $3 / 36$ & $1 / 36$ & $1 / 36$ & $2 / 36$ & \\
\hline
\end{tabular}

\section{Health condition and mortality rate}

Under the condition of the present study all chicks appeared healthy and the total mortality rate was $5.55 \%$ during the whole experimental period without any clear differences among treatments.

These results are in agreement with those obtained by Abhijit Mishra (2013) and Tamman et al. (2015) who reported that, feeding broilers chicks GM as a replacement of soybean meal had no adverse effect on mortality rate.

\section{Carcass characteristics}

The dressing percentages and total edible parts percentages of broiler chicks at 35 days of age as effected by dietary treatments are illustrated in Table (3). It is worth to note that the chicks fed GM diets $\left(\mathrm{T}_{1-4}\right)$ during studied periods (0-35, 0-10, 11-22 and 23-35 days of age) reflected the lowest insignificant results in both dressing and total edible parts percentages compared with control group. The corresponding values for carcass $\%$ ranged between 63.56 and $66.79 \%$, while total edible parts $\%$ ranged between 71.80 and $74.07 \%$. On the other hand, the chicks fed $10 \% \mathrm{GM}\left(\mathrm{T}_{4}\right)$ gave the lowest figures of 63.56 and $68.79 \%$ for carcass and total edible parts percentages and differences were insignificant compare with other treatments.

However, adding the GM at $10 \%$ as inclusion rate in broiler diets $\left(\mathrm{T}_{1-4}\right)$ showed a little insignificant increase of liver or giblets \% compared with control. The findings of the present study co-relate with the findings Muhammad et al. (2002), Kamran et al. (2002), Lee et al. (2005) and Tmmam et al. (2015), they reported that, the addition of guar meal to experimental diets reflected the lowest in significant results in dressing percentages and dressed weight decreases with increasing level of guar meal. 
Table (3): Effect of feeding different dietary treatments on carcass characteristics of broiler chicks at 35 days of age.

\begin{tabular}{|c|c|c|c|c|c|c|}
\hline \multirow{2}{*}{ Item } & \multicolumn{5}{|c|}{ Treatments } & \multirow{2}{*}{ Sig } \\
\hline & Control & $\mathrm{T} 1$ & $\mathrm{~T} 2$ & T3 & T4 & \\
\hline & \multicolumn{6}{|c|}{ Carcass characteristics \% } \\
\hline $\mathrm{LBW}(\mathrm{g})^{*}$ & $\begin{array}{c}1689.50 \pm 10 \\
44^{\mathrm{a}}\end{array}$ & $1429.00 \pm 10.66^{\circ}$ & $1542.50 \pm 8.69^{a}$ & $526.00 \pm 8.67^{b}$ & $1522.50 \pm 22.32^{b}$ & $* *$ \\
\hline \multirow[t]{2}{*}{ Carcass \% } & $66.79 \pm 0.66$ & $65.79 \pm 1.00$ & $64.92 \pm 0.71$ & $65.01 \pm 0.64$ & $63.56 \pm 0.92$ & N.S \\
\hline & \multicolumn{6}{|c|}{ Giblets parts \% } \\
\hline Liver \% & $2.84 \pm 0.25$ & $3.04 \pm 0.12$ & $3.30 \pm 0.16$ & $3.48 \pm 0.19$ & $3.48 \pm 0.32$ & N.S \\
\hline Gizzard \% & $3.60 \pm 0.28$ & $3.46 \pm 0.16$ & $3.45 \pm 0.39$ & $3.78 \pm 0.05$ & $3.99 \pm 0.25$ & N.S \\
\hline Heart $\%$ & $0.84 \pm 0.08$ & $0.85 \pm 0.09$ & $0.95 \pm 0.05$ & $0.81 \pm 0.08$ & $0.77 \pm 0.03$ & N.S \\
\hline Giblets $\% * *$ & $7.28 \pm 0.43$ & $7.34 \pm 0.33$ & $7.70 \pm 0.44$ & $8.07 \pm 0.63$ & $8.24 \pm 0.53$ & N.S \\
\hline Total edible parts $\% * * *$ & $74.07 \pm 0.46$ & $73.13 \pm 0.87$ & $72.62 \pm 1.20$ & $73.08 \pm 0.36$ & $71.80 \pm 0.91$ & N.S \\
\hline
\end{tabular}

${ }^{*} L B W=$ Live body weight $(g),{ }^{*}$ Giblets $=$ Liver + Gizzard + Heart

$a, b$ and $c$ means the same row with different superscripts are significantly different, sig. $=$ significance, $* *(P \leq 0.01)$, , N.S = Non significant

Control (0 \% GM), T1= (10.0\% GM, Starter, Grower, Finisher diets $), T 2=(10 \%$ GM Starter diet $), T 3=(10 \%$ GM Grower diet $), T 4=(10 \%$ GM Finisher diet $)$.

\section{Carcass parts}

Percentages of breast, thigh, drumstick and wing for the chicks at 35 days of age as affected by different dietary treatments are presented in Table (4). Experimental treatments with GM had no significant effect on studied parameters compared with control, however, breast percentage of chickens fed control diet represented with 96 to $90 \%$ of that feed diet inclusion with GM $\left(\mathrm{T}_{1-4}\right)$. The control group were recorded 45.34 versus $50.51,47.45,48.85$ and $49.72 \%$ respectively $\left(\mathrm{T}_{1-4}\right)$ without any significant differences. On the contrary, were recorded the best thigh percentage chickens fed control diet values compared to other treatments ( 28.02 versus $26.29,27.64,25.88$ and $26.95 \%$ respectively), but the differences between treatments were insignificant.

Table (4): Effect of feeding different dietary treatments on carcass parts of broiler chicks at 35 days of age

\begin{tabular}{lcccccc}
\hline \multirow{2}{*}{ Item } & \multicolumn{5}{c}{ Treatments } & \multirow{2}{*}{ Sig } \\
\cline { 2 - 5 } & Control & T1 & T2 & T3 & T4 & \\
\hline
\end{tabular}

Carcass characteristics \%

Carcass weight(g) $1128.50 \pm 16.94^{\mathrm{a}} 940.00 \pm 9.09^{\mathrm{c}} \quad 1001.50 \pm 14.93^{\mathrm{b}} 992.00 \pm 8.67^{\mathrm{b}} 968.00 \pm 23.03^{\mathrm{bc}} \quad * *$

\begin{tabular}{lllllll}
\hline & \multicolumn{7}{c}{ Carcass parts \% } \\
Breast \% & $45.34 \pm \mathbf{2 . 4 2}$ & $50.51 \pm 0.79$ & $47.45 \pm 1.92$ & $48.85 \pm 1.67$ & $49.72 \pm 0.74$ & N.S \\
Thigh \% & $28.02 \pm 2.14$ & $26.29 \pm 0.49$ & $27.64 \pm 1.19$ & $25.88 \pm 0.88$ & $26.95 \pm 0.60$ & N.S \\
Drumstick \% & $14.95 \pm 0.96$ & $12.84 \pm 0.61$ & $14.39 \pm 0.54$ & $15.21 \pm 0.73$ & $13.13 \pm 0.39$ & N.S \\
Wings \% & $10.69 \pm 0.52$ & $10.69 \pm 0.60$ & $10.35 \pm 0.31$ & $10.06 \pm 0.32$ & $10.20 \pm 0.63$ & N.S \\
\hline
\end{tabular}

$a, b$ and $c$ means the same row with different superscripts are significantly different sig. $=$ significance, ${ }^{* *}(P \leq 0.01)$, N.S = Non significant

Control (0 \% GM), T1 = (10.0\% GM, Starter, Grower, Finisher diets $), T 2=(10 \%$ GM Starter diet $), T 3=(10 \%$ GM Grower diet), T4= (10\% GM Finisher diet $)$. 


\section{El-Faham et al.}

In the same order, drumstick and wings percentages showed the same trend, in which control treatment reflected the highest figures compared with other treatments, except $\mathrm{T}_{3}$ in drumstick, however, the differences failed to be insignificant.

These findings are in agreement with those reported by Tyagi et al. (2011) who stated that feeding broiler chicks roasted guar meal for six weeks had no significant effect on carcass traits and cut up parts. On the same order, Tammam et al. (2015) found that there were negative effects of GM in carcass characteristics and some carcass parts percentages which were more prominent in higher inclusion rate than lower ones.

\section{Tibia measurements}

Data for some tibia measurements are summarized in Table (5). Experimental treatments with GM $\left(\mathrm{T}_{1-4}\right)$ had no significant effect on studied parameters compared with control. The corresponding values for wet tibia weight $(\mathrm{g})$ ranged between 7.89 and $8.87(\mathrm{~g})$, Tibia length $(\mathrm{mm})$ ranged between 8.25 and 8.83 and Tibia seedor index (SI) ranged between 0.45 and 0.53 . On the other hand, the broiler chicks fed GM diet $\left(\mathrm{T}_{1}\right)$ gave the lowest values of $7.89 \mathrm{~g}, 8.25 \mathrm{~mm}$ and 0.45 for tibia weight, tibia length and SI and the differences were insignificant compared with control group.

Table (5): Effect of feeding different dietary treatments on Tibia measurements

\begin{tabular}{lcccccc}
\hline \multirow{2}{*}{\multicolumn{1}{c}{ Items }} & \multicolumn{7}{c}{ Treatments } & \multirow{2}{*}{ Sig } \\
\cline { 2 - 7 } & Control & T1 & T2 & T3 & T4 & \\
\hline Wet Tibia weight/g & $\mathbf{8 . 8 7} \pm 0.26$ & $\mathbf{7 . 8 9} \pm 0.36$ & $\mathbf{8 . 2 8} \pm 0.29$ & $\mathbf{8 . 1 7} \pm \mathbf{0 . 3 1}$ & $\mathbf{8 . 5 1} \pm 0.48$ & N.S \\
Wet Tibia \%* & $\mathbf{0 . 5 2 5} \pm \mathbf{0 . 0 1 4}$ & $\mathbf{0 . 5 5 2} \pm \mathbf{0 . 0 2 3}$ & $\mathbf{0 . 5 3 6} \pm 0.016$ & $\mathbf{0 . 5 3 5} \pm 0.023$ & $\mathbf{0 . 5 5 9} \pm 0.034$ & N.S \\
Tibia length(cm) & $\mathbf{8 . 8 3} \pm 0.06$ & $\mathbf{8 . 2 5} \pm 0.41$ & $\mathbf{8 . 3 3} \pm 0.29$ & $\mathbf{8 . 2 5} \pm 0.16$ & $\mathbf{8 . 6 0} \pm 0.24$ & N.S \\
Tibia width (cm) & $\mathbf{6 . 2 6} \pm 0.25$ & $\mathbf{6 . 2 6} \pm 0.25$ & $\mathbf{6 . 0 0} \pm 0.11$ & $\mathbf{6 . 0 0} \pm 0.41$ & $\mathbf{5 . 7 5} \pm 0.25$ & N.S \\
Tibia seedor** & $\mathbf{0 . 5 3} \pm 0.004$ & $\mathbf{0 . 4 5} \pm 0.040$ & $\mathbf{0 . 5 1} \pm 0.030$ & $\mathbf{0 . 4 8} \pm 0.017$ & $\mathbf{0 . 4 7} \pm 0.021$ & N.S \\
\hline
\end{tabular}

*\% of live body weight, ** Seedor index (tibia dray weight, $\mathrm{g} /$ tibia length, $\mathrm{cm}$ ), $a, b$ and $c$ means the same row with different superscripts are significantly different sig. = significance, , N.S = Non significant

Control (0 \% GM), T1= (10.0\% GM, Starter, Grower, Finisher diets $), T 2=(10 \%$ GM Starter diet $), T 3=(10 \%$ GM Grower diet $), T 4=(10 \%$ GM Finisher diet $)$.total edible parts $=$ Hot carcass weight + giblets weight .

In the same trend, Tammam et al. (2015) concluded that seedor index and tibia breaking strength $\left(\mathrm{kg} / \mathrm{cm}^{2}\right)$ for broiler fed high GM (19 or 38\% in starter, grower and finisher diets) were significantly lowest than for the control group, although, no significant differences were detected among low levels of GM ( 4.75 or $9.50 \%$ in starter, grower and finisher diets).

\section{CONCLUSION}

Using guar meal as a replacement for soybean meal at $10 \%$ level in broiler diets may not be beneficial and further research is needed to determine a more accurate level of inclusion rate for better performance and carcass traits.

\section{REFERENCES}

Abhijit Mishra, Samir Jumar Sarkar, Subhasish Ray and Supipto Haldar (2013). Effects of roasted guar korma and supplementation of maa performance and carcass traits of commercial broiler chicken. Veterinary World, EISSN, 6: 2231.

Ambegaokar, S.D.; J.K. Kamath and V.P. Shinde (1969). Nutritional studies in protein of 'gawar (Cyamopsis tetragonoloba). J. Nutr. Diet, 6: 323-328. 
Anderson, J.O. and R.E. Warnick (1964). Value of enzyme supplements in rations containing certain legume seed meals or gums. Poultry Sci., 43: 1091-1097.

Cheng, Z. (2004). Evaluation of guar meal as a source of prebiotic galactomannans for laying hens. Ph.D. Diss. Texas A\&M Univ., College Station, T.X.

Conner, S. (2002). Characterization of guar meal for use in poultry rations. Ph.D. Dissertation Texas A\&M University, College Station, T.X.

Daskiran, M.; R.G. Teeter; D.W. Fodge and H.Y. Hsiao (2004). An evaluation of endo-B-D-mannanase (Hemicell) effects on broiler performance and energy use in diets varying in B-mannan content. Poultry Sci 83: 662-668.

Duncan, D.B. (1955). The Multiple Range and Multiple F- Tests. Biomethics, 11: 1-42.

Elham, S.M. Ahmed (2016). Evaluation of Guar meal korma feed as a feed ingredient for local laying hens. M.Sc. Thesis, University of Ain-Shams.

Feed composition Table for Animal and Poultry feedstuffs used in Egypt (2001). Technical Bulletin Nr. 1, Central Lab for feed and food, Ministry of Agriculture Egypt.

Gibson, G.R. and M.B. Roberfroid (1995). Dietary modulation of the human colonic microbiota: Introducing the concept of prebiotics. Journal of Nutrition, 125: 1401-1412.

Hajati, H. and M1. Rezaei (2010). The application of prebiotics L in poultry production. International Journal of Poultry Science, 9: 298-304.

Hajati, H.; A. Hassanabadi and N. Afzali (2012). Effect of prebiotic(Bio-MOS) on broiler breeder performance and immunity system. 3rd International Veterinary Poultry Congress. Tehran, Iran. Page, 145.

Kamran, M.; T.N. Pasha; A. Mahmud and Z. Ali (2002). Effect of commercial enzyme(Natugrain) supplementation on the nutritive value and inclusion rate of guar meal in broiler rations. International Journal of Poultry Science, 1(6): 167-173.

Larhang, R. A. and M. Torki (2011). Evaluating performance of broilers fed guar meal-included diet supplemented by enzyme. Researches of The First International Conference (Babylon and Razi Universities), 243-247.

Lee, J.T.; C.A. Bailey and A.L. Cartwright (2003a). Guar meal germ and hull fractions differently affect growth performance and intestinal viscosity of broiler chickens. Poultry Sci 82: 1589-1595.

Lee, J.T.; S. Conner Appleton; A.U. Haq; C.A. Bailey and A. Cartwright (2004). Quantitative measurement of negligible trypsin inhibitor activity and nutrient analysis of guar meal fractions. J. Agric. Food Chem., 52: 6492- 6495.

Lee, J.T.; C.A. Bailey and A.L. Cartwright (2003b). Beta- mannanase ameliorates viscosity-associated depression of growth in broiler chickens fed guar germ and hull fractions. Poultry Sci., 82: 19251931.

Lee, J.T.; S. Connor-Appleton; C.A. Bailey and A.L. Cartwright (2005). Effects of guar meal by-product with and without beta mannanase Hemicell on broiler performance. Poultry Sci., 84: 1261-1267.

Mevliit, G.; S. Yasar and J.M. Forbes (2004). Performance and some digesta parameters of broiler chickens given low or high viscosity wheat-based diets with or without enzyme supplementation. Turk J. Vet. Anim. Sci., 28: 323-327.

Michele, W.D.; C.M. Parsons and M.R. Bedford (2000). Effect of various soybean meal sources and Avizyme on chick growth performance and ileal digestible energy. J. Appl. Poultry Res., 9: 74-80.

Mohammad, A.G.; B. Dastar; A.H. Nameghi; G.H. Tabar and M.S. Shargh (2012). Effects of guar meal with and without B-mannanas enzyme on performance and immune response of broiler chicks. International Research Journal of Applied and Basic Sciences, vol. 3(S): 2785-2793.

Muhammad, K.; T.N. Pasha; A. Mahmud and Z. Ali (2002). Effect of commercial enzyme (natugrain) supplementation on the nutritive value and inclusion rate of guar meal in broiler rations. International Journal of Poultry Sci., 1(6): 167-173.

NRC (1994). National Research Council, Nutrient Requirements of Poultry. 9th Ed, National Academic of Science. Washington, DC. USA. 


\section{El-Faham et al.}

Patel, M.B. and J. McGinnis (1985). The effect of autoclaving and enzyme supplementation of guar meal on the performance of chicks and laying hens. Poultry Sci., 64: 1148-1156.

Sanders, M.E. and J.H. Veld (1999). Bringing a probiotic containing functional food to the market. Microbiological, product, regulatory and labeling issues. Antonia Van Leeuwenhoek, 76: 293-315.

SAS Institute (2004). SAs User's Guide. Release 8.2. Ed. SAS Institute Inc. Cary. NC. industrial and farm by-products in growing poultry rations. Ind. J. Vet. Sci., 32: 74-84.

Saxena, U.C. and K. Pradhan (1974). Effect of high protein levels on the replacement value of guar meal (Cyamopsis tetragonoloba) in layer's ration. Ind. J. Anim. Sci, 44: 190-193.

Seedor, T.G.; H.A. Quarruccio and D.D. Thompson (1991). The bisphosphonate alendronate (MK-217) inhibits bone less due to ovariectomy in rats. J. of bone and Mineral Res., 6: 339-346.

Srivastava, S.; K. Aness and R. Ramani (2011). Promise of guar meal. Science Report, November, Page, 33-39.

Tammam, M.; Ibrahim, S.A.; El-Faham, A.I. and Hemid, A.A. (2015). Effect of partial replacement of soybean meal with Guar Meal on performance and carcass traits on broiler chickens. Egyptian J. Nutri and Feeds 2: 305-313.

Tyagi, P.K; A.B. Mandal and P. Tyagi (2011). Utilization of roasted guar (Cyamopsis tetragonoloba) korma in the diet of broiler chickens. Indian Journal of Poultry Science Vol., 46(3): 326-329.

Vohra, P. and F.H. Kratzer (1964b). Growth inhibitory effect of certain polysaccharides for chickens. Poultry Sci., 43: 1164-1170.

تأثير التحول من كسب فول التباتبات العظويا إلى كسب الجوار فى علائق بدارى التسمين على الأداء الإنتاجى وصفات

أحمد إبراهيم الفحام"، أحمد عبد المقصود عبد الحميد**، وأيمن محمد حسن"، وإكرامى منتصر خليفه"*

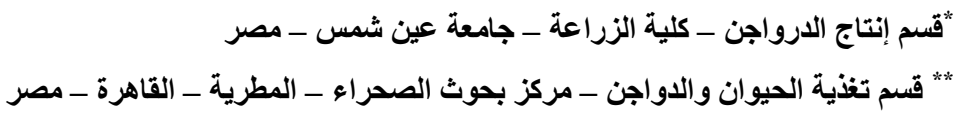

يهدف البحث لدراسة تأثير استخدام • (\% كسب الجوار كبديل لكسب فول الصويا في علائق بدارى التسمين على الأداء الإنتاجي

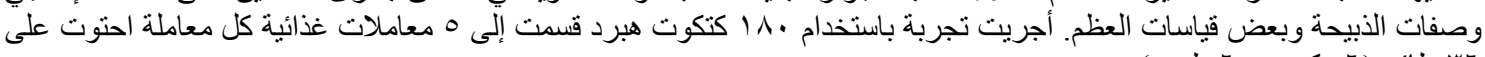
דr طائر (7 مكرر × 7 طبور ).

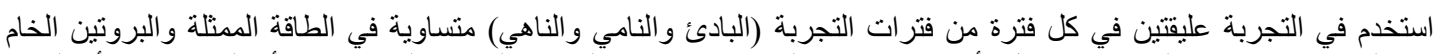

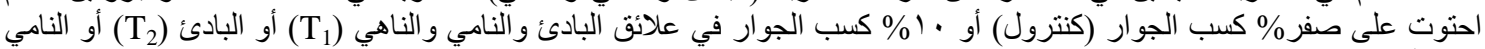

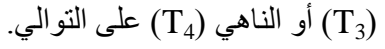

أوضحت النتائج أن:

ا ـ استخدام • ( \% كسب الجوار في علائق بدارى التسمين (T-4) خفض معنويًا الوزن الحي و الوزن المكتسب ومعامل التحويل ץ ـ استخدام • 1\% كسب جوار لم تؤثر على استهلاك العلف وسجلت الطيور بالمعاملات (T-3) أقل القيم.

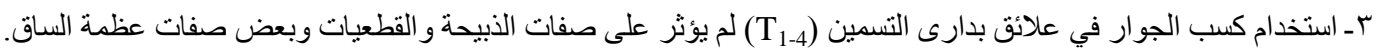

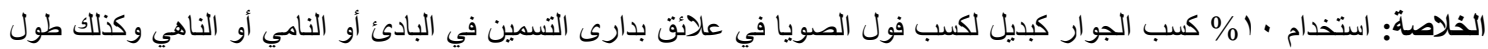

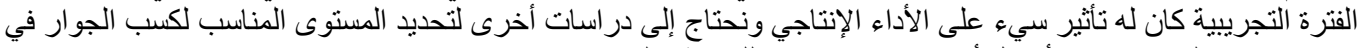

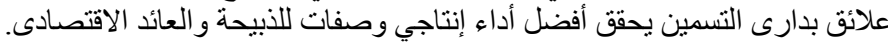

